\title{
GEOELECTRIC MODELING OF SUPERGENIC MANGANESE OCCURRENCE IN HELIODORA REGION, SOUTHERN MINAS GERAIS
}

\author{
César Augusto Moreira', Samuel Siqueira Reis², \\ Walter Malagutti Filho ${ }^{1}$ and Marco Antônio Fontoura Hansen ${ }^{3}$
}

\begin{abstract}
This paper discusses the results of the combined application of electric resistivity and induced polarization methods into a mineral occurrence of manganese of supergenic origin, characterized by oxides of manganese and iron with terrain to powdery texture, arising from weathering of spessartite contained in metasediments. From the measurements of electrical resistivity it was possible to recognize a concentric zone in $2 \mathrm{D}$ inversion models, with values between $73 \Omega$.m and $380 \Omega$.m, coinciding with the most enriched portion of the soil in oxides. The 2D inversion models for chargeability obtained near the profile of exposed soil allowed for delimitating the mineralized extension, characterized by values below $5 \mathrm{mVN}$. The 3D modeling generated by interpolation of $2 \mathrm{D}$ inversion models enabled for a morphological analysis of the occurrence, characterized by a broad range (about $50 \mathrm{~m}$ ) visible in field, but restricted to about 10 meter in depth, between horizons $\mathrm{B}$ and $\mathrm{C}$ of the soil profile. The restriction in depth can be associated to the precipitation of lixiviate metals in the alteration profile, to the interface of oxidation-reduction caused by the cutting in the terrain, which provides aeration and evapotranspiration of the soil. The results reveal the potential for morphological detailing of supergenic mineralization in a fast and quick way, by the combined use of geoelectrical methods and the evaluation of data via 3D modeling.
\end{abstract}

Keywords: mineral exploration, oxide, resistivity, chargeability, 3D modeling.

RESUMO. Este trabalho discute os resultados de uso combinado dos métodos da Eletrorresistividade e Polarização Induzida numa ocorrência mineral de manganês de origem supergênica, caracterizada por óxidos de manganês e ferro com textura terrosa, oriundos do intemperismo de espessartita contida em metassedimentos.

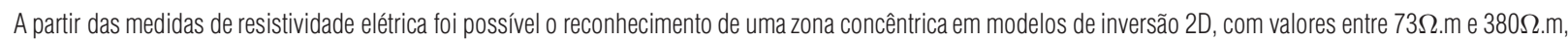
coincidente com a porção mais enriquecida em óxidos. Os modelos de inversão 2D para cargabilidade obtidos próximos no perfil de solo exposto, permitiram delimitar toda a extensão mineralizada, caracterizada por valores abaixo de $5 \mathrm{mV} / \mathrm{N}$. 0 modelamento 3D gerado por interpolação de modelos de inversão 2D, possibilitou uma análise morfológica da ocorrência, caracterizada por uma extensa faixa (cerca de $50 \mathrm{~m}$ ) visível em campo, mas restrita a cerca de $10 \mathrm{~m}$ de profundidade, basicamente entre os horizontes B e C do perfil de solo. A restrição em profundidade pode estar associada a precipitação de metais lixiviados, na interface de oxidação-redução proporcionada pelo corte no terreno para construção da estrada, que promove aeração e evapotranspiração do solo. Os resultados revelam o potencial de detalhamento morfológico de mineralizações supergênicas de forma rápida e expedita, pelo uso combinado de métodos geoelétricos e avaliação de dados via modelamento 3D.

Palavras-chave: exploração mineral, óxido, resistividade, cargabilidade, modelamento 3D.

\footnotetext{
1 Universidade Estadual Paulista - UNESP, Geoscience and Exact Science Institute, Applied Geology Department, Rio Claro Campus, 24-A Avenue, 1515, P.0. Box 178, 13506-900 São Paulo, SP, Brazil. Phone: +55(19) 3526-9322 - E-mails: moreirac@rc.unesp.br; malaguti@rc.unesp.br

2Universidade Estadual Paulista - UNESP, Geoscience and Exact Science Institute, Rio Claro Campus, 24-A Avenue, 1515, P.0. Box 178, 13506-900 São Paulo, SP, Brazil. Phone: +55(19) 3526-2819 - E-mail: samuel.sgeol@gmail.com

3 Universidade Federal do Pampa - UNIPAMPA, Av. Pedro Anunciação, s/n, Vila Batista, 96570-000 Caçapava do Sul, RS, Brazil. Phone: +55(55) 3281-9000

- E-mail: mafhansen@gmail.com
} 


\section{INTRODUCTION}

The mineral sector comprises the steps of research, mining, transformation and consists in the basis for several productive systems. Its present participation in the Internal Gross Revenue (PIB in Brazil) is of $4,2 \%$ and represents about $20 \%$ of Brazilian exports, by means of a productive chain that generates 1 million of direct jobs, equivalent to $8 \%$ of industrial jobs (MME, 2010). The mineral inputs that presently highlight Brazil in the international scenario are the niobium, iron, bauxite, manganese and copper, besides gold and ornamental rocks (MME, 2010).

Of utmost importance for the Brazilian economic growing and maintenance, the mineral sector depends on basic geological researches for the amplification of known deposits and in process of mining, besides the finding of new mineral occurrences and deposits. (Moon et al., 2006). This set of activities is named mineral research, which gathers a series of steps on planning and strategy based upon the mineral input of interest, which vary from the genetic modeling and form of occurrence in the geological environment, methods and procedures of investigation, as geophysics and geochemistry, to economy conditionings, like demand, Market value and future forecasts (Maranhão, 1985; Pereira, 2003).

Studies that aim at regional targets or structures with mining potential are based upon airborne survey or in products of remote sensors (Maas et al., 2003; Pascholati et al., 2003; Soares et al., 2004; Carvalho et al., 2006; Menezes et al., 2006). Works on mineral research in detail of localized targets by means of terrestrial geophysics research are relatively scarce (Mantovani et al., 2008; Moreira et al., 2014).

An intrinsic peculiarity to this sector with direct impact on the research procedures is the present value and future projections about the price of mineral commodities. Projections or expectations on the fall in prices result in costs cutting, reduction in the rhythm of researches and concentration of works in targets of higher economical potential, or is, higher levels associated to low mining costs. On the other hand, scenarios of rising prices for present or future projects enable for the research in little known areas and of low content occurrence, high-risk areas around the investment that can result in promising findings and of great financial return.

In conditions of little contrast of physical properties between mineralized zone and sterile soil/rock, geophysical studies in mineral occurrences are relevant in the sense of defining limitations in the use of geophysical methods, besides the analysis of the possibility of adaptations in procedures of acquisition and analysis of data, aiming to perfect and advance in applications of this tool of mineral research.
The present work evaluates the applicability of geophysical methods of electric resistivity and induced polarization in a manganese mineral occurrence of supergenic origin, originated from the alteration of spessartite crystals and formations of oxides in profiles of soil, previously recognized in field works. By means of $2 \mathrm{D}$ and $3 \mathrm{D}$ modeling, are also analyzed the lateral and in depth continuities of the mineralized zone.

\section{LOCATION AND GEOLOGICAL CONTEXT}

The city of Heliodora is located at South-southeast of the State of Minas Gerais, near the cities of Natercia at SE, Careaçu at NW and Lambari at NE. The area can be accessed from the BR 381 (Fernão Dias road), by means of the exit 821 and access to the road MG 456 until the city of Heliodora. The access to the area from the city center is made by the old road that connects the cities of Heliodora and Natércia, precisely located in the crest of Manuela Hill, near the cities borders (Fig. 1).

The region of Natércia is located in the High Rio Grande Folding Strip located at the South of the São Francisco craton, with a trapezoidal shape with approximately $350 \mathrm{~km}$ extension and WSW-ENE general heading, from the Paraná Basin from West, to the region between Paranaíba-Barbacena-Juiz de Fora (Trouw et al., 1983; CPRM, 1988). It is contained in the domain of the Mantiqueira Province which, according to Heilbron et al. (2004), is a Neoproterozoic orogenic system that extends from the South of the State of Bahia to Uruguay, constituting a strip in NE/SW direction and having more than $3000 \mathrm{~km}$ in length. This region represents the Meridional Tocantins Orogen developed at the South of the São Francisco Craton. It is related to the agglutination of the Occidental Gondwana, during the Braziliano Orogenic Collage in the Brazilian southwest (Trouw et al., 1994; Campos-Neto et al., 2004).

This folding strip is characterized by polycyclic evolution, with evidences of several tectono-metamorphic events that affected both the supracrust sequences and the archean basin. Its probable age is Lower Proterozoic, being its highest metamorphic peak occurring during the Uruçuano Cycle (CPRM, 1988).

The main structures of this range were consolidated in the Jequié Cycle (2.5 G.a). The process of continental collision favored the formation of marginal basin, with initial fine earth sedimentation, intercalated with volcaniclastic, spillage and maphic and ultramaphic intrusions. This set was subjected to a ductile shearing of low angle, besides a metamorphism of green shale facies to amphibolite during the Uruçuano Cycle. This phase was followed by wide foldings associated to transpressive shearing zones and metamorphism in green shale facies (CPRM, 1988). 


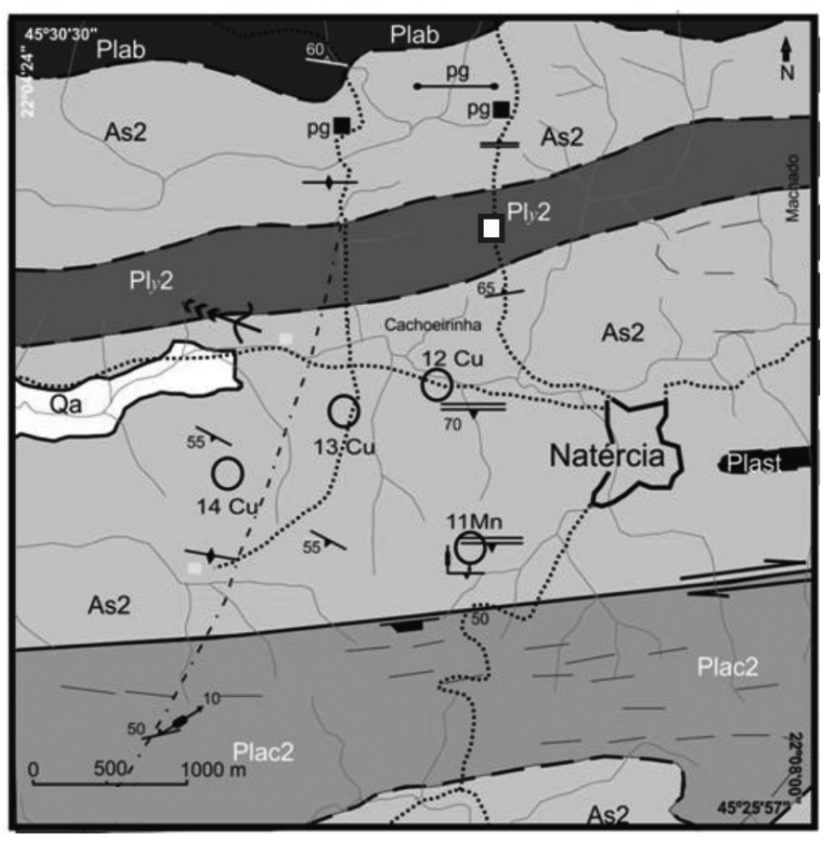

Quaternary

Qa Alluvium deposit

Paraisópolis Complex

$\mathrm{Pl} 2$ Biotite-granite-gneiss

Study area

Andrelândia Group

Plab Amphibole-biotite paragneiss; micaschists, quartzits

Plast Muscovite quartzits; sillimanite-quartz schist

Plac2 Sillimanite-garnet-biotite schist; paragneiss; quartzits

Silvianópolis Complex

As2 Hornblend-biotite-tonelite-gneiss; biotite amphibolites

\# Alignment in shear transcurrence, with direction

O Morphology of mineral deposit undeterminated

- Shear zone Schistosity with dip indicated and measured

- Approximate contact $\longrightarrow$ Foliation/banding milonitic with dip indicated

$\bar{r}-$ Frcture inferred $\rightarrow$ Joint fill

reld axis $\quad$ m $p$ Mineral occurence (pegmatite)

$\stackrel{\mathrm{pg}}{\longrightarrow}$ Pegmetite dike Deposit of surface alteration

$\leftarrow$ Foliation/banding gnaissic of the transposition with dip indicated and vertical

...... Road $\sim$ Drainage Narto City

Figure 1 - Location and geological context.

This resulted in a complex tectonic framework that does not fit to the concepts of conventional tectonic movements, directed to the craton, and not even to an independent belt of Brazilian moving bands (Ribeiro et al., 1995).

In the Heliodora region, the base is arken/paleoproterozoic, constituted by heterogenic orthognaisses, of monzonitic to granodioritic composition. Locally there are subordinated intercalations of anphibolites and metaultramaphics.

The supracrust rocks correspond to a pile of $1500 \mathrm{~m}$ of metassediments pertaining to the Andrelândia nappe, formed by gneisses, quartzites and schists, with discreet intercalation of metamaphic and metaultramaphis rocks (Trouw et al., 1983). The Socorro-Guaxupé nappe represents a fragment of deep continental crust arising from the root of magma arc installed in the eastern border in the Paranapanema paleocontinent (Campos-Neto et al., 2004).

There are also sin a tarde tectonic granites and Cenozoic alluvial and colluvial sediments and lateritic detritus coverings which fill and cover the modern valleys. Two major metamorphic events related to Brazilian thermo-tectonic affected the region. The first is related to the Meridian Brasilia Range and generated conditions of high pressure and moderate temperature. It is compatible with facies varying from medium green schist, amphibolite and granulite, locally with retroeclogite facies, and increases from North to South. The second event was conditioned by the Ribeira Track and generated high temperature conditions and intermediate pressure and an intense granite genesis associated.
Under the local geological context, the mineral occurrence selected for study is part of a set of several targets that occur in isolation in the regions of Careaçu, Heliodora and Natércia. The most known occurrences are related mainly to gondite bodies interspersed in muscovite quartzite and Muscovite schist belonging to the Lambari Complex, whose genesis is attributed to the oxidation of spessartite and precipitation of iron and manganese oxides (Fig. 2).

The selected target for study is possibly associated with the filling of fractures by manganese oxides in the Lambari Complex paragnaisses, classified as an instance of gondite registered at the South of Natércia, in the form of centrimetrical irregular bodies interspersed to the enveloping rock. In the visible portions of the ground, the mineralization is characterized by an association of pyrolusite, wad, psilomelane, goethite, hematite and magnetite, with terrain to puvirolent texture.

\section{MATERIALS AND METHODS}

The initial procedures in the area of studies consisted in preliminary geological reconnaissance to identify evidence of supergenic mineralization of manganese in soil profiles exposed along the road. Selected the most promising in terms of lateral continuity and thickness, 6 lines of electrical tomography were programmed for joint implementation of measures of electrical resistivity and chargeability in the time domain, through the WennerSchlumberger arrangement, with spacing of $5 \mathrm{~m}$ between sensors, $10 \mathrm{~m}$ between rows and $95 \mathrm{~m}$ in length of each line (Fig. 3). 

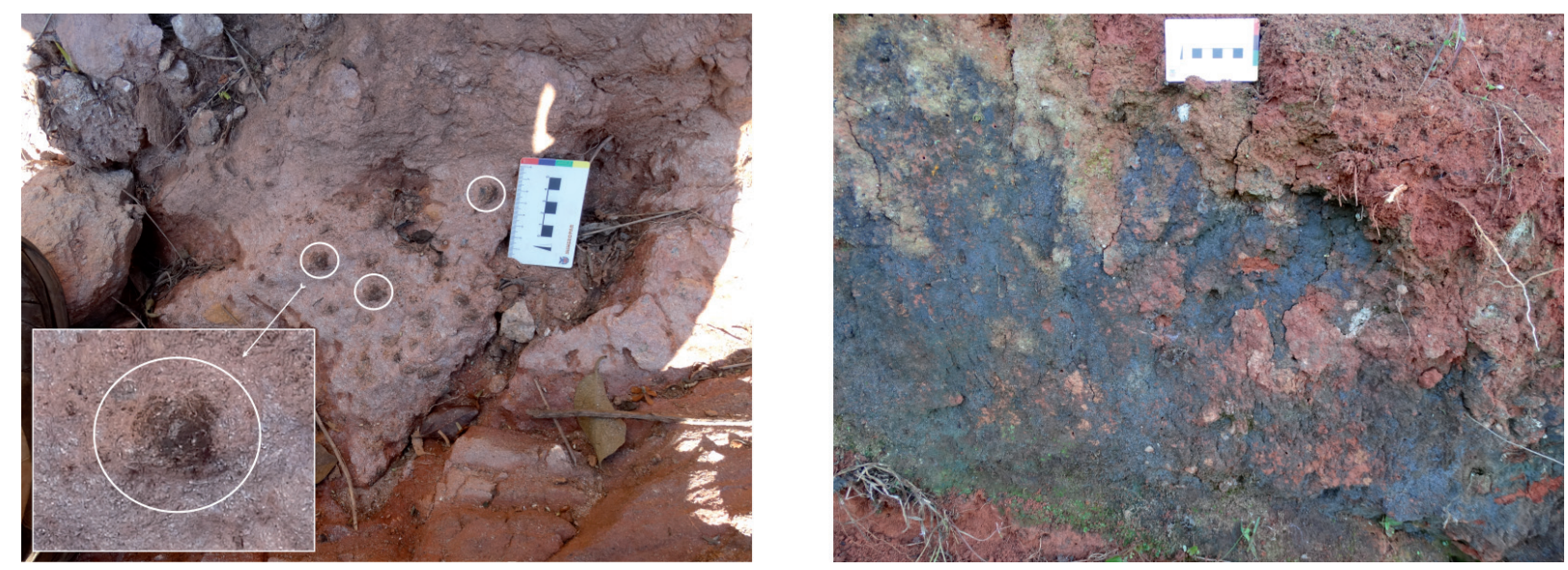

Figure 2 - Local geology. A) Muscovite schist grenade, with details of spessartite crystals (Mn). B) Manganese oxides impregnations in soil profile.

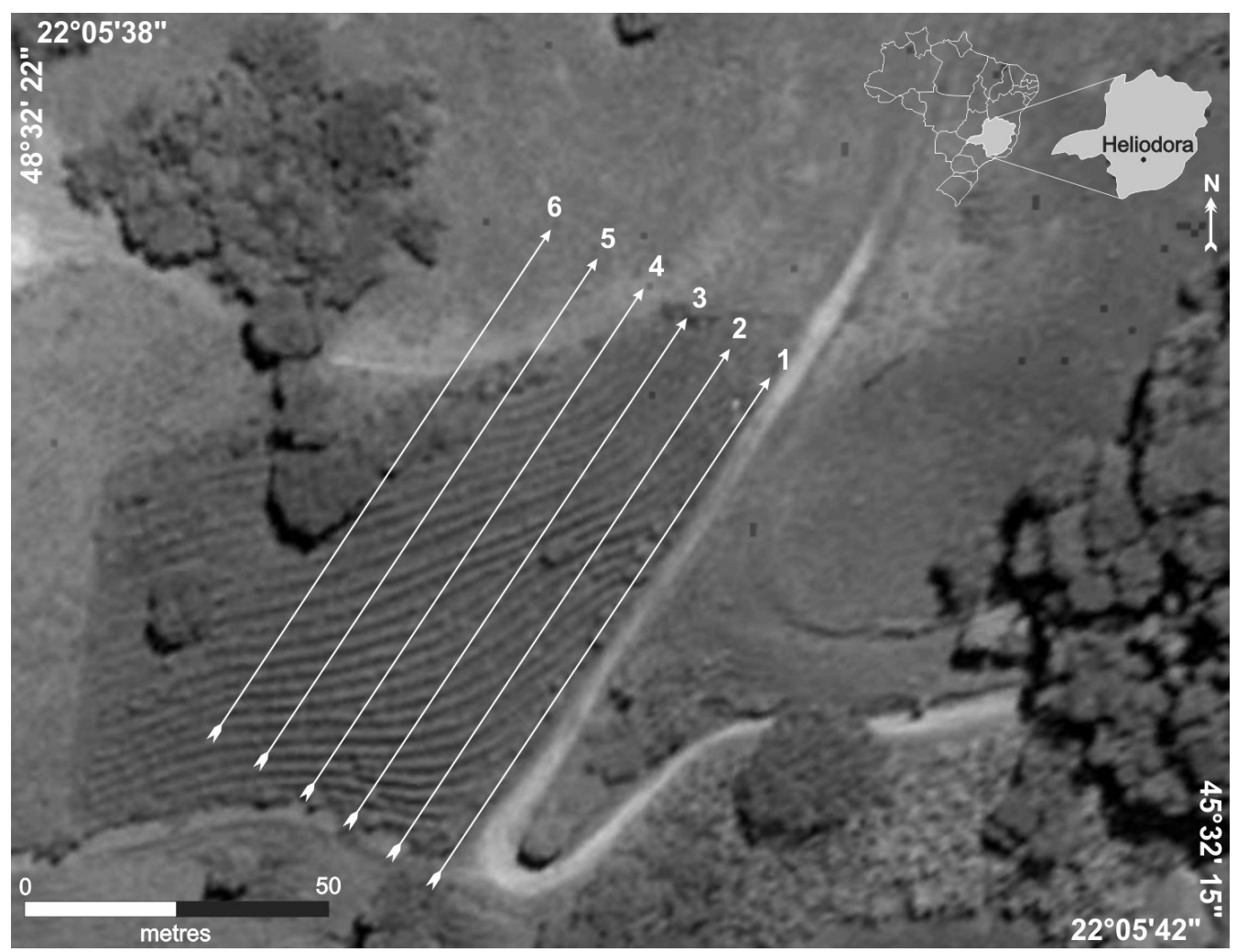

Figure 3 - Placement of geophysical acquisition data lines.

The acquisition of geophysical data counted on the Terrameter LS, developed by ABEM (Sweden), which consist in an integrated module of transmission and reception of signals and enables for the performance of electric resistivity, induced polarization and spontaneous potential essays, by means of continuous automatic acquisition in multi-cable system originated from initial programing of the equipment. The programing of the equipment counted on the following configurations: maximum current of $200 \mathrm{~mA}$, minimum current of $100 \mathrm{~mA}$, transmission time of the current of $1 \mathrm{~s}$, time of reading after the current cut of $0.2 \mathrm{~s}$ and reading in two fixed windows of $0.1 \mathrm{~s}$ each.

Non-polarizable electrodes were used, characterized by a porous base container filled with a solution saturated in copper sulfate $\left(\mathrm{CuSO}_{4}\right)$, which is inserted in a copper stick and connected 
to the multi-cable system. This system enables the flow of electrical current and the significant reduction in parasite currents and contact resistance.

The measurements acquired in the field were processed in the Res2dinv program and resulted in inversion models in terms of distance $\times$ depth, with logarithmic graphic scale and intervals of interpolation of values in colors. This is a program that automatically determines a two-dimensional model of subsurface, from data of resistivity or chargeability obtained in essays of electrical routing (Griffiths \& Barker, 1993).

The $2 \mathrm{D}$ model used in the program divides the pseudosection into rectangular blocks, which will represent the pseudosection through the adjustment of the field measurements. This optimization focus on reducing the difference among the apparent resistivity values calculated and measured in field, by the resistivity adjustment of the block models, which difference is expressed by the RMS (Root Mean Square) error (Loke \& Barker, 1996).

The numeric product of two-dimensional inversion of the data from each section was gathered in a single spreadsheet, which unites the positions of the readings along the lines (variable " $x$ "), spacing among lines (variable "y"), depth modeled by the inversion (variable "z") and the value for the electrical resistivity (variable "R").

This spreadsheet was used to generate 3D visualization models, in a routine of basic steps adopted in mineral research. In this case, the sampling plan is frequently defined from statistical, structural, spatial placement criteria, among others (Moon et al., 2006). A simple procedure is sampling by a set of holes perpendicular to the main axis of the structure, followed by a parallel set of hollowing lines.

The resolution of the sampling net is conditioned to the spacing among holes, lines of holes and among quantities of samples collected by holes. Anyway, the analytical result of the samples is sampled and modeled in two-dimensional terms and later interpolated in tri-dimensional terms. Each point of the final 3D model is transformed in a block, with dimensions conditioned to statistical criteria and of sampling net, to which content based in chemical analysis and a mean value of density related to the rock that hosts the mineral is attributed. The relationship between content and volume enables for the calculation of reserves and the economic feasibility of the business (Moon et al., 2006). The models of visualization were generated by application of the Minimum Curvature Algorithm.

Geophysical 3D visualization models derived from 2D sections provide for a very wide comprehension on the complexity of geological structures, rocks or mineral deposits (Kemp,
2000; Zanchi et al., 2009; Chen, 2011; Aizebeokhai et al., 2011; Wang et al., 2011; Houlding, 2012; Akiska et al., 2012; Moreira et al., 2016).

\section{RESULTS}

For the purposes of direct correlation between the occurrence described in field and geophysical data, inversion models were selected obtained from the rows closest to the outcropping mineralization (Fig. 4).

In the data related to the electric resistivity it was possible the recognition of only the central portion and more enriched of the mineralized zone, characterized by resistivity values between $73 \Omega \mathrm{m}$ and $380 \Omega \mathrm{m}$. Areas recognized in the field and described as more sparse and peripheral to the center of the occurrence, are not identifiable in the sections of electrical resistivity.

On the other hand, Induced Polarization data present a large predominance of values up to $5 \mathrm{mV} / \mathrm{V}$ at half the initial sections. The large area of low chargeability values highlighted in the section for line 1 (Fig. 4), corresponds basically to the entire area of the mineral occurrence, comprising a richer central zone (between $25 \mathrm{~m}$ and $40 \mathrm{~m}$ from the beginning of the sections) and their extremes with sparse deliberate releases (from $0 \mathrm{~m}$ to $50 \mathrm{~m}$ from the beginning of the sections).

The integration of the physical parameters measured from the line closest to the outcropping mineralized area allows for defining a signature of low resistivity and low chargeability for the central zone and low chargeability for more widespread peripheral areas.

The integration of the physical set of sections of electrical resistivity and chargeability in 3D visualization models provides an in-depth analysis on the ground and the possible continuity of mineralization (Fig. 5).

The portion of low resistivity highlighted in the sections is also present in the 3D visualization model, although characterized by comparatively lower values, being this difference attributed to smoothing provided by the use of minimum curvature algorithm, adopted in the preparation of models.

The range of low resistivity values present in deeper levels is similar to that described for the central mineralized zone, but attributed to the increase in the humidity level of the soil, also noted in some spots along the profile of the studied soil, under the occurrence of water punctual outcrops.

The extension of low resistivity zone along the soil profile has about $45 \mathrm{~m}$. Its continuity at depth is relatively restricted in no more than $10 \mathrm{~m}$ deep into the soil profile. The range of coverage in the case of the low chargeability zone has approximately 

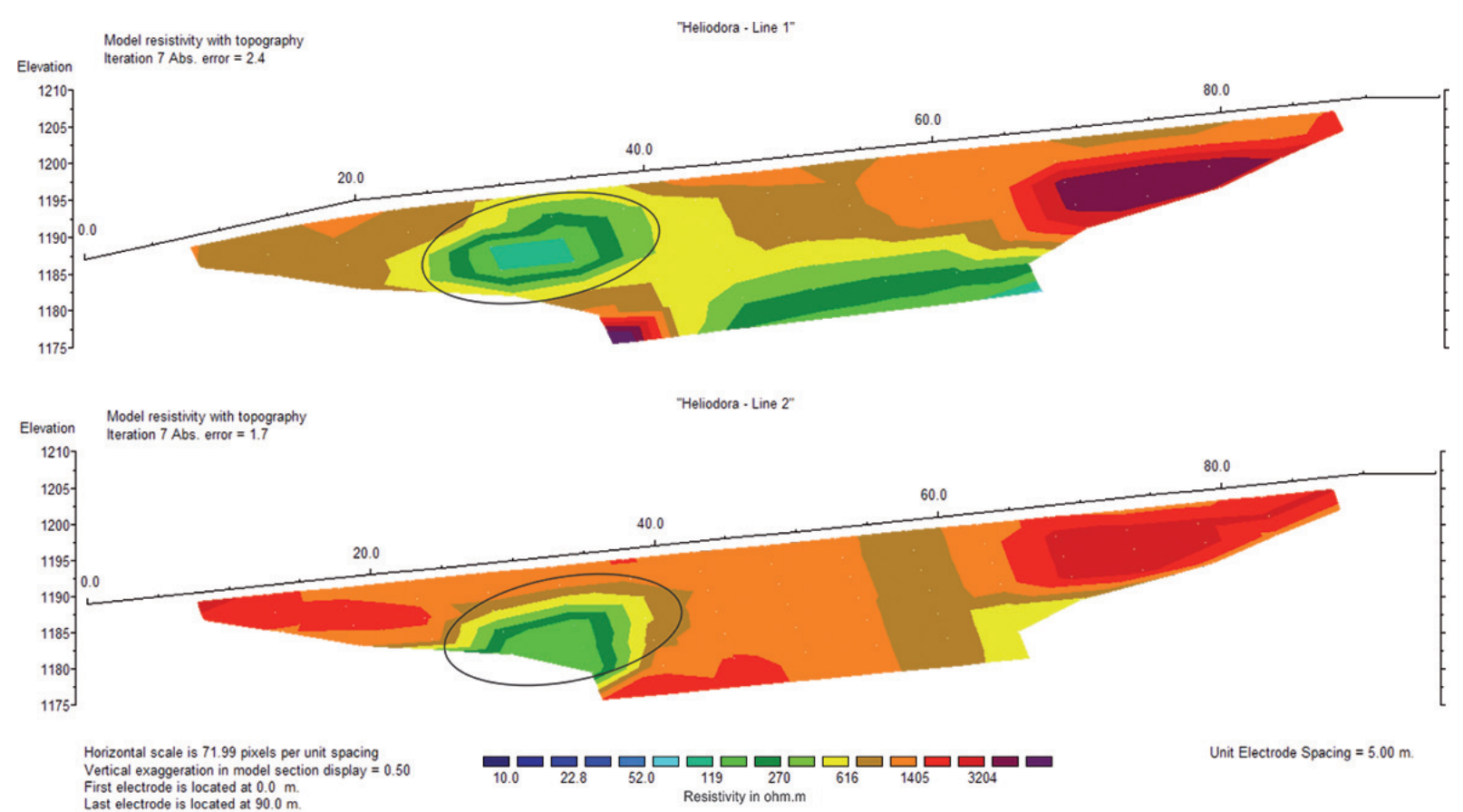

Firtst electrode is located at $0.0 \mathrm{~m}$.
Last electrode is located at $90.0 \mathrm{~m}$.

Unit Electrode Spacing $=5.00 \mathrm{~m}$
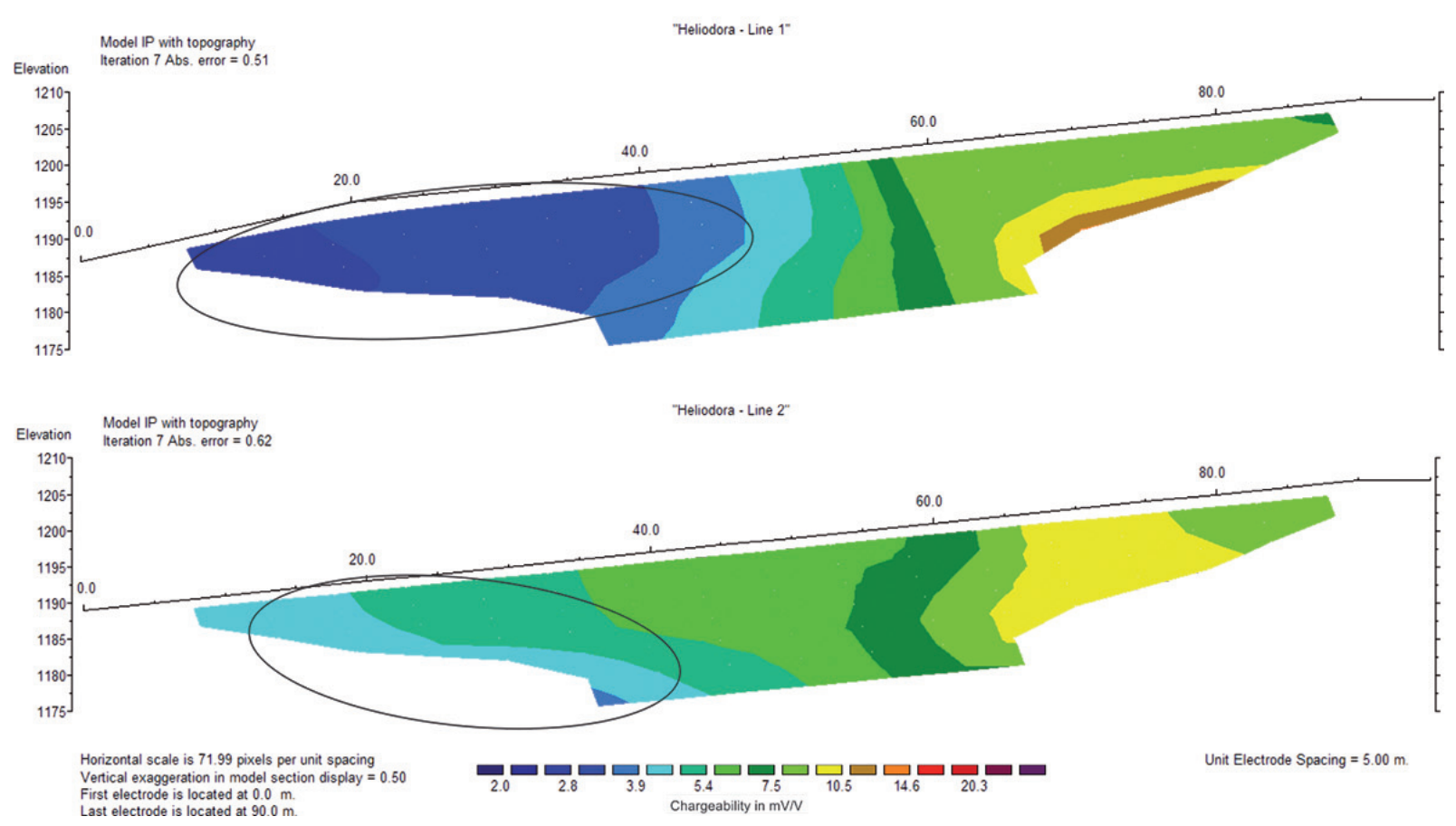

Figure 4 - Models of inversion of resistivity and chargeability closest to the outcropping mineral occurrence.

$50 \mathrm{~m}$ of lateral continuity, but even more limited in depth, with a maximum of approximately $5 \mathrm{~m}$ within the soil profile. The overlapping of areas of low resistivity and low chargeability clearly reveals such differences (Fig. 5).
The characterization of a mineralized zone extensive in width and restricted in depth can be attributed to the genesis of this type of mineral deposit. The weathering modifies and redistributes the mineral content in the different levels of the deposit, 


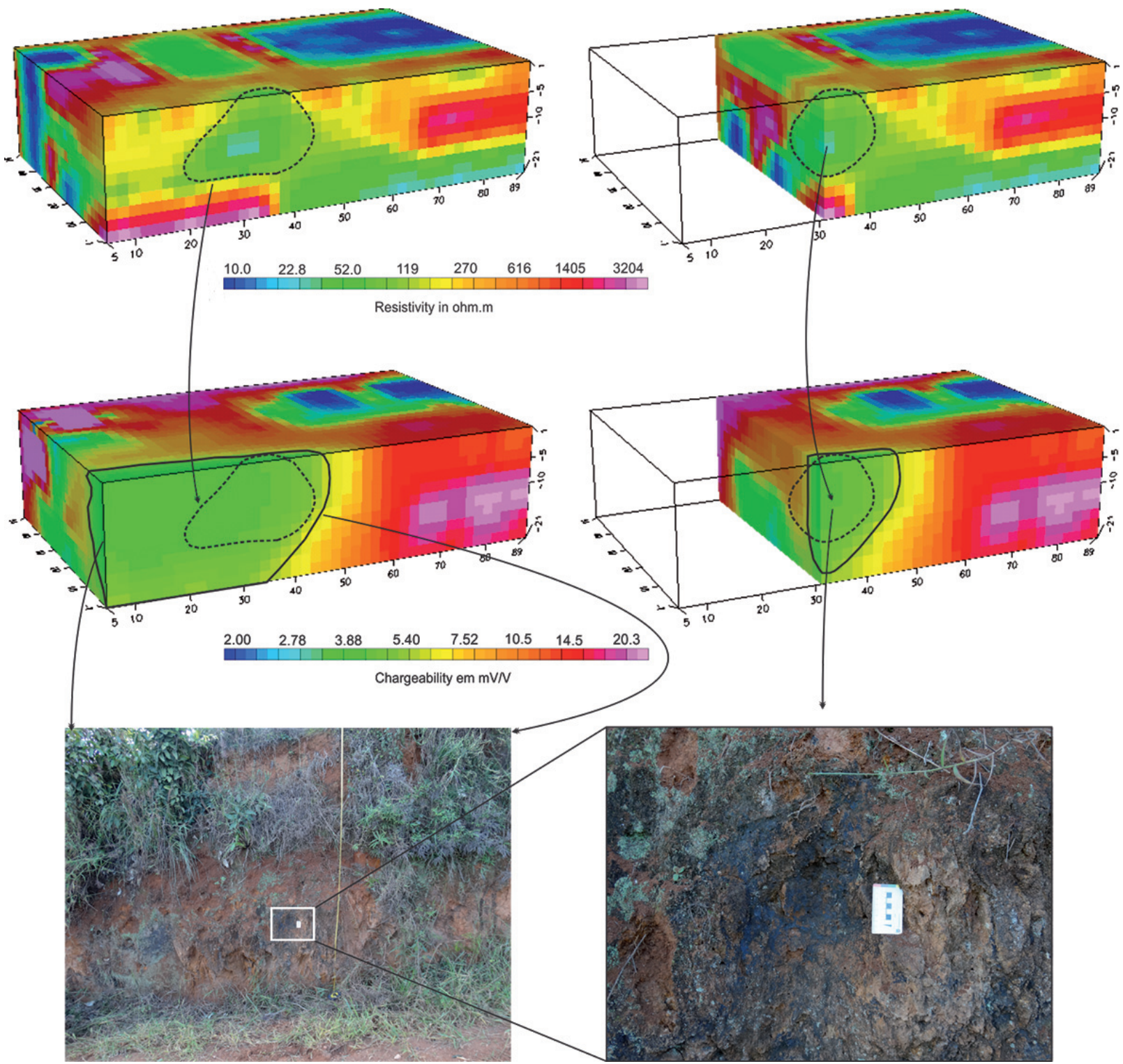

Figure 5 -3D visualization models in terms of resistivity and chargeability, highlighting areas correlated to outcropping mineral occurrence.

originating new zones of elements and content inside the alteration profile, both vertically and horizontally. This mechanism can provide for the economy of a series of supergenic accumulations in iron, nickel and manganese, by the leaching of accessory and undesired components (Borchert, 1970; Roy, 1992; Valeton, 1994; Roy, 1997; Maynard, 2003).

The leaching and transport of manganese are governed by processes and mechanisms similar to those that govern iron, or is, most of the manganese compounds is solute in water neutral to acids and precipitated in alkaline waters. The manganese leached from the rocks is carried from the vertical and lateral soil profile and the carried as carbonated composites or particles by natural Waters of slight acid pH to the water bodies (Frakes \& Bolton, 1992).

Two factors are crucial to the development of the supergenic deposits, which are the presence of humid tropical climate and the content of manganese in the rock (Peters, 1978; Roy, 1997). Humid tropical climate favors high concentrations of humic acids in face of the abundant vegetal covering and constant variation in the phreatic level, which favor the precipitation of chemical elements like manganese. Basic, ultrabasics and some metamorphic rocks present significant amounts of manganese, with 
the genesis of economic accumulations when weathered. Secondary concentrations of manganese from these rocks are developed in the form of lateritic profiles that can reach up to $30 \mathrm{~m}$ depth (Valeton, 1994).

The oxidated crusts can generate hardened horizons positioned in deep levels of ferralitic soils, resulting from the migration of manganese/iron solutions originated from upper portions and very drained. The solutions migrate vertically in the profile and carry the manganese, with solubility much higher when compared to iron, until the deposition generally between horizons $B$ and C (saprolitic) (Evangelou, 1998; Hillel et al., 2004).

Such accumulations can reach concentrations up to $80 \%$ of manganese oxides, essentially constituted by psilomelane and pirolusit of fibrous, massive or botryoid aspect (Taylor, 2011).

In this sense, the concentration of manganese oxides in the profile of the studied soil and such occurrence restricted to few meters in depth can be related to the lateral migration of solutions enriched in manganese between horizons $B$ and $C$ and the precipitation of metals in a front of reduction-oxidation, coinciding with an interface of soil exposition, where evapotranspiration, aeration and formation of oxides occur, as suggested in McKenzie (1972), Loganathan \& Burau (1973), Gadde \& Laitinen (1974), Hem (1978), Stone \& Morgan (1984), Hem et al. (1985), Junta \& Hochella (1994).

\section{CONCLUSIONS}

The joint acquisition of electric resistivity and induced polarization data in soil profile with mineralization in supergenic manganese enabled the definition of a geoelectrical signature characteristic for the mineral occurrence.

In models of $2 \mathrm{D}$ inversion in terms of electrical resistivity, it was possible to define the definition of a concentric zone of low resistivity, coinciding with an area of intense dissemination of manganese oxides recognized in the field. In terms of chargeability, it was possible to define a range of occurrence of values of up to $5 \mathrm{mV} / \mathrm{N}$, which basically coincides with the maximum extension of the manganese occurrence.

The results demonstrated the efficiency of the application of the induced polarization method in the definition of the dissemination of supergenic manganese in profiles of soil, whereas the applicability of the electric resistivity is apparently restricted to the concentration of relatively high contents concentrations. The pattern of low chargeability (values below $5 \mathrm{mV} / \mathrm{V}$ ) in relation to the sterile soil (values between $5 \mathrm{mV} / \mathrm{V}$ and $20 \mathrm{~m} / \mathrm{V}$ ) can be attributed to the leaching and to the carrying of argil minerals of the soil profile during the process of supergenic concentration of manganese.
It is relevant to highlight the polarizability associated to the presence of argil minerals in geological materials, a mechanism of considerable capacity for the generation of electrical potential. It is probable that the phenomenon of the electronic polarization is irrelevant in case of oxide accumulation in face of the low intensity of values obtained, although it is understood as the process responsible for the high polarizability of areas with disseminated sulfides.

The interpolation of parallel lines and the generation of $3 D$ visualization models demonstrated satisfactory results in terms of morphological analysis of the mineral occurrence, under the view of the measures physical parameters. From the analogy between the visible extension of manganese oxides and their area of higher concentration in the profile of the studied soil, with a characteristic geoelectrical signature, it was possible a very reasonable analysis of the continuity of the mineralized zone in depth.

Apparently restricted to few meter in depth, its origin from the mineral occurrence can be attributed to the precipitation of manganese oxides in a reduction-oxidation interface, originated from the flow of aqueous solutions that percolated and leachated crystals of spessartite (Mn garnet) during the process of intemperism of the metasedimentary sequence. This interface is represented by the area exposed in the road, where there is aeration and evapotranspiration, mainly in the layer formed between the $B$ and $C$ soil horizons. To prove and complement the geophysical study, works of quantification of contents by sampling means and chemical analysis are recommended.

Although this and other dozens of occurrences of manganese described for the region are of small size, the eventual existence of high contents, ease of access to the mining of an easily digging material and prone to the separation by magnetic processes, can be something considerable in a scenario of new applications or of increase in the demand for manganese in the domestic market.

\section{ACKNOWLEDGEMENTS}

The authors are thankful to Fundação de Amparo à Pesquisa do Estado de São Paulo (FAPESP), for financial support of the project "Geophysical prospection in supergenic manganese occurrence in Natércia region, Minas Gerais Southern" (Processs FAPESP n. 2013/09219-5).

\section{REFERENCES}

AIZEBEOKHAI AP, OLAYINKA Al, SINGH VS \& UHUEGBU CC. 2011. Effectiveness of $3 \mathrm{D}$ geoelectrical resistivity imaging using parallel 2D profiles. International Journal of the Physical Sciences, 6: 5623-5647. 
AKISKA S, SAYILI IS \& DEMIRELA G. 2013. Three-dimensional subsurface modeling of mineralization: a case study from the Handeresi (Çanakkale, NW Turkey) Pb-Zn-Cu deposit. Turkish Journal of Earth Sciences, 22: 574-587. Available at:

$<$ http://journals.tubitak.gov.tr/earth/issues/yer-13-22-4/yer-22-4-5-

1206-1.pdf>. Access on: September 2016.

BORCHERT H. 1970. On the ore-deposition and geochemistry of manganese. Mineralium Deposita, 5(3): 300-314.

CAMPOS-NETO MDC, BASEI MAS, VLACH SRF, CABY R, SZABÓ GAJ \& VASCONCELOS P. 2004. Migração de orógenos e superposição de orogêneses: Um esboço da colagem brasiliana no sul do cráton do São Francisco, SE-Brasil. Geologia USP. Série Científica, 4(1): 13-40. Available at: <http://www.revistas.usp.br/guspsc/article/ view/27389/29161 > . Access on: September 2016.

CARVALHO LMM, PIRES ACB, OLIVEIRA CG, MORAES RAV \& BLUM MLB. 2006. Processamento e interpretação dos dados magnetométricos aéreos do Projeto Itabira-Ferros, MG: uma ferramenta no auxíio ao mapeamento geológico-estrutural e à prospecção mineral. Revista Brasileira de Geociências, 36(1): 85-92.

CHEN D. 2011. Advances in Data, Methods, Models and Their Applications in Geoscience. InTech, Rijeka, 348 pp.

CORTÊS ARP, MOREIRA CA, VELOSO DIK, VIEIRA LB \& BERGONZONI FA. 2016. Geoelectrical prospecting for a copper-sulfide mineralization in the Camaquã sedimentary basin, Southern Brazil. Geofísica Internacional, 55(3): 165-174. Available at: <http://www.geofisica.unam.mx/ unid_apoyo/editorial/publicaciones/investigacion/geofisica_internacional/anteriores/2016/03/1cortes.pdf>. Access on: September 2016.

CPRM - Companhia de Pesquisa de Recursos Minerais. 1988. Programa de Levantamentos Geológicos Básicos do Brasil; carta geológica, carta metalogenética/previsional - Escala 1:50.000 (Folha SF.23-Y-B-II-2 Heliodora). Estado de Minas Gerais. CPRM/DNPM, Brasília, Brazil, 199 pp.

EVANGELOU B. 1998. Environmental soil and water chemistry: principles and applications. John Wiley \& Sons, New York, 577 pp.

FRAKES L \& BOLTON BR. 1992. Effects of ocean chemistry, sea level, and climate on the formation of primary sedimentary manganese ore deposits. Economic Geology, 87(5): 1207-1217.

GADDE RR \& LAITINEN HA. 1974. Studies of heavy metal adsorption by hydrous iron and manganese oxides. Analytical Chemistry, 46: 20222026.

GRIFFITHS DH \& BARKER RD. 1993. Two-dimensional resistivity imaging and modelling in areas of complex geology. In: CASSINIS R, HELBIG K \& PANZA GF (Eds.). Geophysical Exploration in Areas of Complex Geology, I. J. Appl. Geophys., 29: 211-226.

HEILBRON M, PEDROSA-SOARES AC, CAMPOS NETO MC, SILVA LC, TROUW R \& JANASI V. 2004. A Província Mantiqueira. In: MANTESSO
NETO V, BARTORELLI A, DAL RÉ CARNEIRO C \& BRITO NEVES BB DE (Eds.). Geologia do Continente Sul-Americano, Evolução da obra de Fernando Flávio Marques de Almeida. Editora Beca, São Paulo, Brazil, 203-235.

HEM JD. 1978. Redox processes at the surface of manganese oxide and their effects on aqueous metal ions. Chemical Geology, 21: 199218.

HEM JD, ROBERSON CE \& LIND CJ. 1985. Thermodynamic stability of $\mathrm{COOOH}$ and its coprecipitation with manganese. Geochimica and Cosmochimica Acta, 49: 801-810.

HILLEL D, ROSENZWEIG C, POWLSON D, SCOW K, SINGER M \& SPARKS D. 2004. Encyclopedia of soils in the environment-volume 1. Academic Press, New York, 2002 pp.

HOULDING SW. 2012. 3D Geoscience Modeling: Computer Techniques for Geological Characterization. Springer, Cambridge, 309 pp.

JUNTA JL \& HOCHELLA MF Jr. 1994. Manganese (II) oxidation at mineral surfaces: A microscopic and spectroscopic study. Geochimica and Cosmochimica Acta, 58: 4985-4999.

KEMP EA. 2000. 3-D visualization of structural field data: examples from the Archean Caopatina Formation, Abitibi greenstone belt, Québec, Canada. Computers \& Geosciences, 26: 509-530.

LOGANATHAN P \& BURAU RG. 1973. Sorption of heavy metal ions by a hydrous manganese oxide. Geochimica and Cosmochimica Acta, 37: 1277-1293.

LOKE MH \& BARKER RD. 1996. Rapid least-squares inversion of apparent resistivity pseudosections by a quasi-Newton method. Geophysical Prospecting, 44: 131-152.

MAAS MVR, OLIVEIRA CG, PIRES ACB \& MORAES RAV. 2003. Aplicação da geofísica aérea na exploração mineral e mapeamento geológico do setor sudoeste do cinturão cuprífero Orós-Jaguaribe. Revista Brasileira de Geociências, 33(1): 279-288.

MANTOVANI MSM, SHUKOWSKY W, NEVES BBB \& RUGENSKI A. 2008. Gravimetric Study of a potential mineral deposit in Itapororoca Region, Brazil. Geophysical Prospecting, 56: 751-760.

MARANHÃO RJL. 1985. Introdução à Pesquisa Mineral. Banco do Nordeste do Brasil, Fortaleza, Brazil, 796 pp.

MAYNARD JB. 2003. Manganiferous sediments, rocks, and ores. Treatise on Geochemistry, London, 7: 289-308

McKENZIE RM. 1972. The sorption of some heavy metals by the lower oxides of manganese. Geoderma, 8: 29-35.

MENEZES PTL, ROIG HL, SILVA GB \& MANE MA. 2006. Prospecção mineral no Grupo Paranoá. Reprocessamento de dados aerogamaespectométricos e interpretação integrada a imagens TM - Landsat 5. Brazilian Journal of Geophysics, 24(3): 343-355. Available at: 
$<$ http://www.scielo.br/pdf/rbg/v24n3/a04v24n3.pdf>. Access on: September 2016.

MME - MINISTÉRIO DE MINAS E ENERGIA. 2010. Plano Nacional de Mineração 2030 (PMN - 2030). MME, Brasília, Brazil, 178 pp.

MOON CJ, WHATELEY MEG \& EVANS AM. 2006. Introduction to Mineral Exploration. Blackwell Publishing, Oxford, $499 \mathrm{pp}$.

MORAIS MC, MARTINS JR PP \& PARADELLA WR. 2011. Mapping Iron-Mineralized Laterite Environments based on Textural Attributes from MAPSAR Image Simulation-SAR R99B (SIVAM-SIPAM) in the Amazon Region. Brazilian Journal of Geophysics, 29(1): 99-111.

MOREIRA CA, LOPES SM, SCHWEIG C \& SEIXAS AR. 2012. Geoelectrical prospection of disseminated sulfide mineral occurrences in Camaquã sedimentary basin. Brazilian Journal of Geophysics, 30(2): 169-179. Available at: <http://sys2.sbgf.org.br/revista/index.php/rbgf/article/ view/90/44>.

MOREIRA CA, BORGES MR, VIEIRA GL, MALAGUTTI FILHO W \& FERNANDES MMA. 2014. Geological and geophysical data integration for delimitation of mineralized areas in a supergene manganese deposits. Geofísica Internacional, 53: 199-210. Available at: <http://www.elsevier.es/es-revista-geofisica-internacional-80-articulogeological-geophysical-data-integration-for-S0016716914715004>. Access on: September 2016.

MOREIRA CA, LAPOLAMM \& CARRARA A. 2016. Comparative analyzes among electrical resistivity tomography arrays in the characterization of flow structure in free aquifer. Geofísica Internacional, 55(2): 119-129. Available at: <http://www.scielo.org.mx/pdf/geoint/v55n2/0016-7169geoint-55-02-00119.pdf>. Access on: September 2016.

PASCHOLATIEM, SILVA C, COSTA SS, OSAKO LS, AMARAL G \& RODRIGUEZ IP. 2003. Novas ocorrências de Urânio na região de Lagoa Real, a partir da superposição de dados geofísicos, geológicos e de sensoriamento remoto. Revista Brasileira de Geociências, 33(2): 91-98. Available at: <http://www.rbg.sbgeo.org.br/index.php/rbg/article/view/ SR-12/747>. Access on: September 2016.

PEREIRA RM. 2003. Fundamentos de Prospecção Mineral. Interciência, São Paulo, Brazil, 167 pp.

PETERS WC. 1978. Exploration and mining geology. John Wiley and Sons, New York, 696 pp.

RIBEIRO A, TROUW RAJ, ANDREIS RR, PACIULLO FVP \& VALENÇA JG. 1995. Evolução das bacias proterozóicas e o termo-tectonismo Brasiliano na margem sul do cráton do São Francisco. Brazilian Journal of Geology, 25(4): 235-248. Available at:
$<$ http://www.rbg.sbge0.org.br/index.php/rbg/article/viewFile/530/ 223>. Access on: September 2016.

ROY S. 1992. Environments and processes of manganese deposition. Economic Geology, 87(5): 1218-1236.

ROY S. 1997. Genetic diversity of manganese deposition in the terrestrial geological record. Geological Society, London, Special Publications, 119(1): 5-27.

SOARES MS, KOPPE JC \& ROLIM SBA. 2004. Interpretação das anomalias de potássio hidrotermal e parâmetro $F$ da região do Complexo Bossoroca, São Sepé, RS. Revista da Escola de Minas, Ouro Preto MG, 57(4): 39-44. Available at: <http://www.scielo.br/pdf/rem/v57n1/ v57n1a08.pdf > Access on: September 2016.

STONE AT \& MORGAN JJ. 1984. Reduction and dissolution of manganese (III) and manganese (IV) oxides by organics. 2. Survey of the reactivity of organics. Environmental Science and Technology, 18: 617-624.

TAYLOR R. 2011. Gossans and Leached Cappings - Field Assessment. Springer-Verlag, Heidelberg, 165 pp.

TROUW RAJ, RIBEIRO A \& PACIULLO FVP. 1983. Geologia estrutural dos grupos São João del Rei, Carrancas e Andrelândia, sul de Minas Gerais. Anais da Academia Brasileira de Ciências, 55(1): 71-85.

TROUW RAJ, PACIULLO FVP \& RIBEIRO A. 1994. A faixa alto Rio Grande reinterpretada como zona de interferência entre a faixa Brasília e a faixa Ribeira. In: SBG, Congresso Brasileiro de Geologia, 38(3): 234-235.

VALETON I. 1994. Element concentration and formation of ore deposits by weathering. Catena, 21(2): 99-129.

VIEIRA LB, MOREIRA CA, CÔRTES ARP \& LUVIZOTTO GL. 2016. Geophysical modeling of the manganese deposit for Induced Polarization method in Itapira (Brazil). Geofísica Internacional, 55(2): 107-117. Available at: <http://www.elsevier.es/en-revista-geofisicainternacional-80-articulo-geological-geophysical-data-integration-forS0016716914715004>. Access on: September 2016.

ZANCHI A, FRANCESCA S, STEFANO Z, SIMONE S \& GRAZIANO G. 2009. 3D reconstruction of complex geological bodies: examples from the Alps. Computers \& Geosciences, 35: 49-69.

WANG G, ZHANG S, YAN C, SONG Y, SUN Y, LI D \& XU F. 2011. Mineral potential targeting and resource assessment based on $3 \mathrm{D}$ geological modeling in Luanchuan region, China. Computers \& Geosciences, 37 : 1976-1988. 